Esta publicación cientifica en formato digital es continuidad de la revista impresa ISSN-Versión Impresa 0798-1406 / ISSN-Versión on line 2542-3185Depósito legal pp
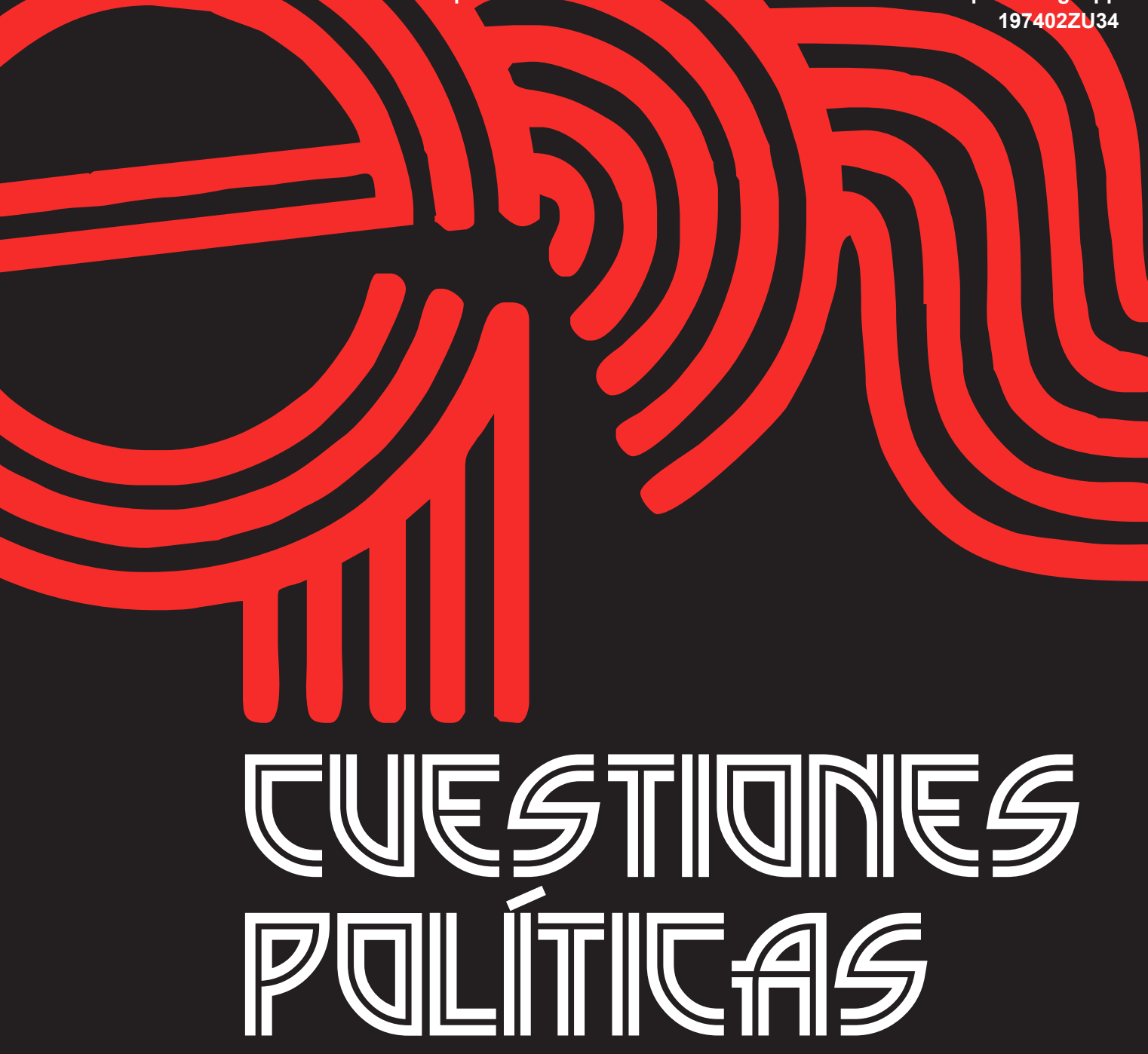

Instituto de Estudios Políticos y Derecho Público "Dr. Humberto J. La Roche" de la Facultad de Ciencias Jurídicas y Políticas de la Universidad del Zulia Maracaibo, Venezuela
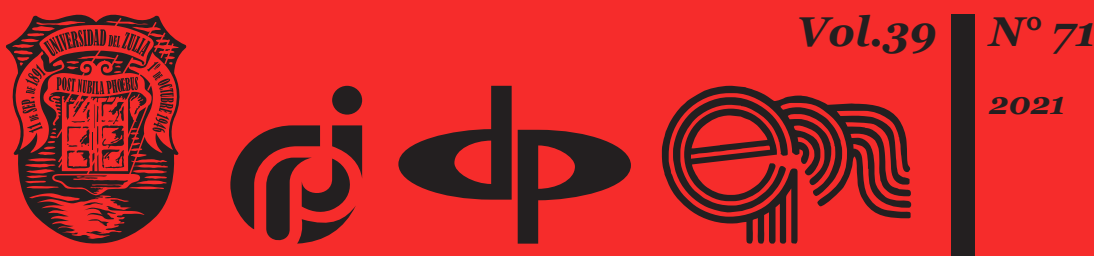


\title{
Restorative and productive methods of environmental management in the implementation of environmental policy
}

\author{
DOI : https://doi.org/10.46398/cuestpol.3971.53
}

Viktoriia Nekhai *

Svetlana Nesterenko **

Oksana Marchenko ***

Svetlana Suprunenko $* * * *$

Tetiana Khrystova $* * * * *$

\section{Abstract}

The objective of this work is to define and base the principles of environmental management through the introduction of regenerative (restorative) and productive methods of environmental policy. The problems were solved with the help of such general and special research methods, such as generalization, systematization, analysis, synthesis, and the empirical method. It is argued that the operation of industrial enterprises without a balanced set of appropriate environmental measures always has negative consequences. The formation of environmental awareness of entrepreneurs, assigning to environmental management the status of a mandatory component of the policy to achieve regional environmental objectives, requires greater attention and effective methodological developments. The strategic directions of ecological development of one of the regions of Ukraine are indicated. The essence of the concept of "environmental management" is defined. The definition of "regenerative method of ecological management" and "productive method of ecological management" is offered. In conclusion, scientific ideas on the feasibility of implementing environmental management in companies are presented. The need for ecological measures for the implementation of ecological policy is based.

Keywords: ecological policy; environmental management; production method; industrial enterprises; regenerative method.

\footnotetext{
Dmytro Motorny Tavriya State Agrotechnological University. ORCID ID: https://orcid.org/oooo0003-1184-6776

** Dmytro Motorny Tavriya State Agrotechnological University. ORCID ID: https://orcid.org/oooo0oo2-8912-838X

*** Bohdan Khmelnitsky Melitopol State Pedagogical University, Ukraine. ORCID ID: https://orcid. org/0000-0002-4727-3183

**** University of State Fiscal Service of Ukraine, Ukraine. ORCID ID: https://orcid.org/oooo-0oo2-45853440

****** Bogdan Khmelnitsky Melitopol State Pedagogical University. ORCID ID: https://orcid.org/oooo0003-1621-695X
} 


\section{Métodos regenerativos y productivos de gestión ambiental en la implementación de la política ambiental}

\section{Resumen}

El objetivo de este trabajo es definir y fundamentar los principios de la gestión ambiental a través de la introducción de métodos regenerativos (restaurativos) y productivos de política ambiental. Los problemas se resolvieron con la ayuda de métodos de investigación tanto, generales y especiales, como la generalización, la sistematización, el análisis, la síntesis y el método empírico. Se argumenta que el funcionamiento de las empresas industriales sin un conjunto equilibrado de medidas ambientales adecuadas siempre tiene consecuencias negativas. La formación de la conciencia ambiental de los empresarios, asignando a la gestión ambiental el estado de un componente obligatorio de la política para lograr los objetivos ambientales regionales, requiere una mayor atención y desarrollos metodológicos efectivos. Se indican las direcciones estratégicas del desarrollo ecológico de una de las regiones de Ucrania. Se define la esencia del concepto de "gestión ambiental». Se ofrece la definición de «método regenerativo de gestión ecológica» y "método productivo de gestión ecológica». Como conclusión se presentan ideas científicas sobre la viabilidad de implementar la gestión ambiental en las empresas. Se fundamenta la necesidad de medidas ecológicas para la realización de la política ecológica.

Palabras clave: políticaecológica;gestiónambiental;métodoproductivo; empresas industriales; método regenerativo.

\section{Introduction}

Environmental issue for the economy of Ukraine is becoming especially relevant since processes of environmental degradation take place in almost all regions of our country, and changed environment has a negative impact on our society. For Ukraine, as a country that is looking for ways to achieve sustainable economic development, the priority is to form a sustainable environmental policy to be enshrined in the overall state development strategy. It is well known that industrial enterprises functioning, which are the basis for any country's economy, always causes negative consequences without mature complex of adequate environmental measures.

They have different power but demand mature complex of overcoming measures. These measures should not only be developed and coordinated by state and regional authorities, but also directly implemented at the enterprise level. General management system of enterprise, without 
alternative, should include department managing environmental safety of economic activity. The activities of industrial enterprises in our country allow us to confirm that these issues are not addressed comprehensively and require special attention and effective development of scientists to improve the methodology of environmental management for the implementation of environmental policy. Such developments should form the basis forming foundations for Ukraine's worthy accession to European community.

M. Zos-Kior, O. Shkurupiy, I. Gnatenko, O. Fedirets, I. Shulzhenko, V. Rubezhanskaya, O. Chygryn, V. Krasniak, L. Lipych, T. Hlubitska, R. Oleksenko, devoted their scientific papers to issues on developing conceptual means, introducing and developing environmental management, environmental bases of economy and management. Issues on ecosystem management are reflected in publications of Gregory McGee, M. Jafari. However, issues on developing environmental management concept, forming entrepreneurs' environmental awareness, assigning environmental management the status of obligatory component of programs to achieve regional environmental goals require heightened attention and further theoretical and methodological developments.

\section{Objectives}

The purpose of this work is to define and substantiate the principles of environmental management through the introduction of regenerative (restorative) and productive methods of environmental policy.

\section{Materials and metnods}

Neoclassical economic theory defines environmental management as integral scientific area. It combines scientific problems of management, environmental management, economy, medicine, law. This synthesis requires creation of unified methodological means for effective interaction of environmental management elements as a holistic system.

To solve the scientific and practical problem, we will consider and substantiate the methods of organizing environmental management for the implementation of environmental policy. According to "type of organization" criterion, we offer to divide them into direct and indirect in relation to solving environmental problems. Each of these approaches has certain positive features, so both might be implemented in practice and be united for implementation in one and the same region.

Direct approach to environmentalization is realized by activity of organizations that directly perform environmentalization functions of 
conditions for society and human existence. Among such organizations, for example, forestry occupies an important place. To clarify the meaning, specify the mission and distinguish from existing ones, we offer to use "productive method of environmental management" concept to define the direct type of organization and implementation of environmental management.

Indirect approach to regional environmentalization lies in introduction and implementation of environmental management at enterprises, which themselves create environmental problems in the region where they are located. To specify this approach more exactly, we offer to use "regenerative method of environmental management" concept. Environmental management carries out its main mission the most completely by implementing regeneration method.

\section{Results and discussion}

Choosing structure and approaches to implement environmental management by this method is to address issue about responsibilities that should be performed by different participants in the process of environmental safety.

From the point of view of regional authorities, first of all, it is necessary to decide whether certain functions for implementing environmental management measures should be entrusted to specialized firms and, if so, what limits of implementation and responsibility they are going to have.

Study of theoretical means and current state of environmental responsibility system allows us to state that environmental goals for regions of Ukraine differ in experience they were set by. But they must be united into a common system for the country. Unifying motivational lever for solving this crucial economic and, at the same time, social problem should be a deep understanding that its solution should ensure healthy existence of humanity, achieve better standard of living, create new jobs, ensure healthy environment, reduce morbidity rate, and therefore, will achieve qualitatively new standard of living and establishment of socio-economic development of regions and economy. This multi-purpose direction is a goal determinant of economic activity environmentalization among other economic problems.

"Regional Report" of Department of Ecology and Natural Resources of Zaporizhia Regional State Administration states that "country should transit to innovation and technological development on the basis of certain priorities in order to form national innovation system and holistic structure of scientific and technical complex in the context of globalization. The main directions of innovative development should be: 
- Ecological restructuring and ecological modernization of production, which involves changing industry structure by reducing demand for products of not environmentally friendly industries or by modernizing enterprises - consumers of such products.

- Developing and using environmental technologies, in particular, using technologies for waste disposal, resources recycling, reclamation of disturbed lands.

- Implementing environmental management systems at industrial enterprises, which is a modern mechanism for managing environmental activities, whose functioning contributes to improvement of enterprises environmental activity.

- Formulating ecological requirements for development of new ones, introduction into practice of strict ecological control of existing technologies in accordance with modern ecological norms and standards" (Department of Ecology and Natural Resources, Regional state administration of Zaporizhzha, Regional report on the state of the environment in Zaporizhia region in 2017, Department of Ecology And Natural Resources, 2018).

The main strategic directions for ecological development of other Ukrainian region, city of Mykolaiv, in 2021 are defined the following:

- Utilization of household and industrial waste.

- Development of public transport and cycling.

- Environmental education.

- Environmental management of the city.

- Rational land use, etc., (Mykolayiv City Council, Ecological policy of the city of Nikolaev, 2021).

One of the first direction positions concerns activity of industrial enterprises, which also substantiates decisive role of introduction and development of environmental management in these and other enterprises. Among indicators of sustainable environmental development are identified, in particular, "sustainability of environmental management" in the direction of increasing percentage of enterprises that carry out environmental management procedures.

Defined areas of innovative development of regional innovation systems and holistic structure of scientific and technical complex, able to function in the context of globalization, indicate necessity to create methodological basis for development of environmental management at industrial enterprises in Ukraine. 
To justify decisive role of implementing environmental management at enterprises, it is necessary to understand its essence. Specialists' and scientists' views on importance of implementing environmental management at enterprises of different economic areas are slightly different, but they are united by common understanding of its mission. Environmental management is "part of entire management system, covering organizational structure, planning activities, allocation of responsibilities, practical work, procedures, processes and resources for development, implementation, achievement of goals, evaluation of environmental policy" (Varfolomeev, 2019).

According to scientists studying issues of environmental management of enterprises, environmental management is aimed at minimizing costs, increasing enterprise's competitiveness and gaining customers' creditworthiness in relations with all involved parts; contributes to effective functioning of entire enterprise's ecological and economic system.

A number of these and other advantages confirm relevance of implementing eco-management at chemical enterprises. It is difficult to disagree with this issue, considering that during the period when state authorities' and Ukrainians' efforts are aimed at creating preconditions for European integration, a country, which does not follow environmental rules of coexistence in the world, might not receive creditworthiness. Scientific developments of individual approaches to consolidation and development of environmental management at enterprises of different economic sectors and different economically based regions of the country are designed to become a guarantee of solving general economic problems.

Ukrainian scientists L. Zos-Kior, M., Shkurupiy, O., Gnatenko, I., Fedirets, O., Shulzhenko, I. \& Rubezhanskaya, V. in their work "Modeling of the process of formation of the investment program of ecological management of an agrarian cluster" Ukraine has “... preconditions to form environmental management system, which is confirmed by existing legal framework for environmental protection. But now it is underdeveloped.

Scattering of regulations relating to environmental management in various laws and regulations of environmental legislation leads to its ineffectiveness. General state of environmental safety in Ukraine is quite complex. There is a wide variety of factors (both natural and anthropogenic) that ambiguate its condition in time-space aspect. This significantly affects environment and leads to deteriorating living conditions. Therefore, there is an urgent need for comprehensive study and solution of problems related to environmental safety (Zos-Kior et al, 2021a). Ensuring study comprehensiveness and solution of problems related to environmental safety is perhaps the most important scientific task in this direction. 
It is worth noting that in the territory of "Zaporizhia oblast" there are such powerful industrial enterprises as private joint-stock companies "Zaporizhzhya Iron Ore Plant", "Zaporizhkoks", "Zaporizhskloflus", "Pology Oil Extraction Plant", public joint-stock companies "Zaporozhye" steel works", "Ukrgrafit", "Zaporizhzhia Ferroalloys Plant", Limited Liability Company "Zaporizhzhya Titanium and Magnesium Plant" and other powerful industrial enterprises. According to "Regional Report" of Department of Ecology and Natural Resources of Zaporizhia Regional State Administration at these enterprises: "...management decisions are made that will increase natural resources efficiency" (Department of Ecology and Natural Resources, Regional state administration of Zaporizhzha, Regional report on the state of the environment in Zaporizhia region in 2017, Department Of Ecology And Natural Resources, 2018: 48).

Among measures are indicated those that are the main peculiarities of environmental management (Fig. 1).

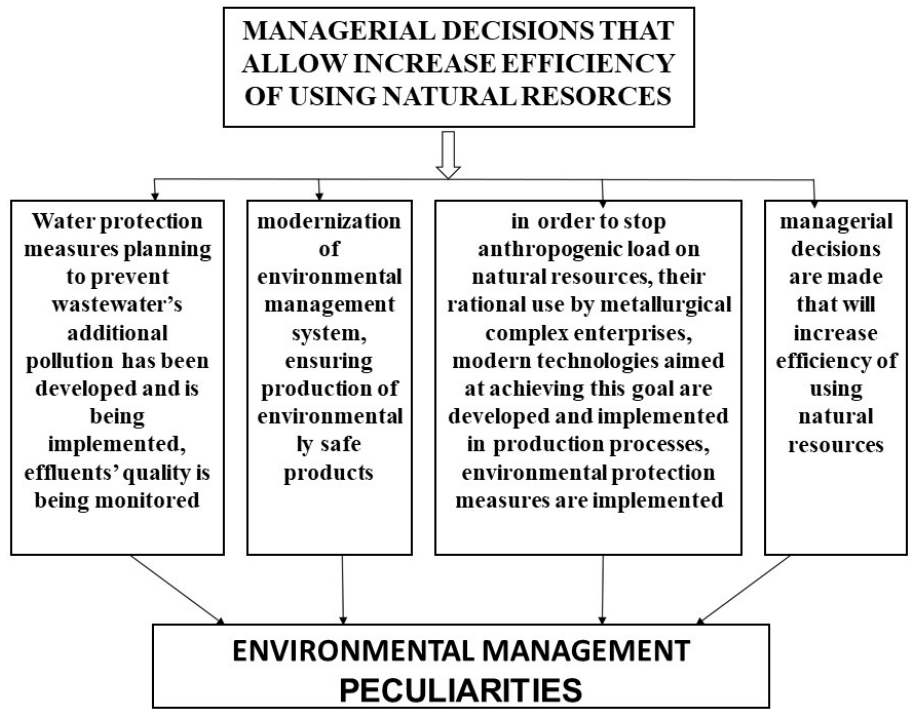

Figure 1. Environmental management peculiarities in Department of Ecology and Natural Resources of Zaporizhia Regional State Administration activities at regional enterprises for efficiency of using natural resources (summarized based on funds (Department of Ecology and Natural Resources, Regional state administration of Zaporizhzha, Regional report on the state of the environment in Zaporizhia region in 2017 , Department of Ecology and Natural Resources, 2018). 

environmental policy

Measures mentioned by Department indicate signs of existence of environmental management in view of purposefulness and complex nature of environmental measures, which are coordinated by regional authorities.

To these measures, in our opinion, and from experience of implementing environmental management, should be added the following:

- Using primary production waste in the same production process from which it is obtained.

- Using production waste in other production processes.

It is obviously considered quite possible at enterprise level under the conditions of purposeful ecological policy and introduction of ecological management which should be presented by effective organizational structure, rational planning of specified actions, allocation of responsibilities, practical work, procedures and resources for development, implementation, achievement of goals, evaluating achievements in implementation of environmental policy.

Studying processes of environmentalization of enteprise production processes, Chygryn, O. and Krasniak, V. (Chygryn et al, 2015) indicate the following functional areas of environmental management : development and implementation of technological processes and schemes that eliminate or minimize waste and emissions of harmful substances water cycles and drainage systems to save and protect against fresh water pollution as one of the most scarce resources. Design and implementation of systems for processing waste production and consumption, return to the main production cycle of secondary material resources.

Development and implementation of fundamentally new processes for obtaining traditional types of products and waste disposal. Creation of regional industrial complexes, whose enterprises relate to waste processing. Obviously, authors point out not only importance to ensure comprehensiveness in solving environmental problems, but also consolidation of efforts in this direction of regional enterprises. This is also confirmed by scientists Zos-Kior M., Shkurupiy O., Gnatenko I., Fedirets O., Shulzhenko I. And Rubezhanskaya V. indicating that: "Existence of contradictions between natural environment and economic activity, including functioning of agricultural clusters, has made essential production transferring to a qualitatively new level associated with adaptation to environmental conditions" (Zos-Kior et al., 2021b: 571).

Authors consider it necessary to establish priority environmental aspects of enterprise, involve stakeholders and parties in planning enterprise's environmental activities, development and coordination of environmental goals and objectives, define criteria and indicators for evaluating results of achieving environmental goals and objectives. Obviously, these measures 
are related to the fact that they can be implemented by environmental management group.

However, as for any enterprise in the region, there are certain obstacles in achieving environmental goals. By analogy: to introduce, for example, marketing, the obstacle is so-called "inertia" of replacing marketing with sales, i.e., partial implementation of marketing functions. Thus, for environmental management system there is a problem of replacing environmental management system with implementation of certain environmental measures, which is neither systematic nor comprehensive.

This study has also identified such a problem as lack of funds for implementing environmental projects, environmental management measures for enterprises and for regional authorities. It is at least indicated by enterprises' representatives and cities and towns authorities, justifying the fact that it is not economically justified to attract additional staff for full functional implementation of environmental management.

But this might be considered as lack of competence using means to implement environmental projects and plans. Thus, according to Department of Ecology and Natural Resources of Zaporizhia Regional State Administration, only 54.03\% of Regional Fund for Environmental Protection funds were used in 2017. And from local funds of environmental protection (village, town, city, rayon) were used only $12.39 \%$ of funds (Department of Ecology and Natural Resources, Regional state administration of Zaporizhzha, Regional report on the state of the environment in Zaporizhia region in 2017, Department Of Ecology And Natural Resources, 2018).

Thus, we can conclude that solving issue of financial support of environmental measures lacks competent management measures to involve them.

The second method of environmental management, productive, which is united with organization mission. This method is implemented at enterprises which form a basis for ecological balance reproduction. One of them - State Enterprise "Melitopol Forestry" of Zaporizhia Regional Department of Forestry and Hunting is located in the southern part of Zaporizhia oblast on the territory of 3 administrative rayons: Melitopol, Yakymiv and Pryazovsk. It is relatively middle-sized enterprise of steppe zone with consequently average volume of forestry - 3065.3 thousand $\mathrm{UAH}$, industrial production -565.5 thousand UAH, agriculture -594.7 thousand UAH.

Enterprise's management uses scientifically substantiated methods to improve production, uses the latest technologies, forms of labour organization, which allows to increase production, produce new products, create new jobs. For such enterprises, environmental management is the basis of management process. Activity goal, organization mission, strategic 
and tactical development plans are carried out in the direction of creating environmental safety of our country by means of implementing ecosystem management as a kind of environmental management.

According to forest ecosystem management researcher Gregory McGee's point of view, "forest ecologists have accumulated extensive experience in environmental impact of traditional forest management practices and realized importance to integrate knowledge about relationship between forest structure and biodiversity into modern management practices.

This contributed to development of forest ecosystem management, which was applied by various foresters on public and private land plots in the hope of improving ecological condition of forests in the world" (McGee, 2015). Ecosystem management unites mission of regional forest management and environmental safety management of the region, it reproduces what is lost in the result of production activities of industrial enterprises. It is implied to support ecosystem structure, models, and processes within natural boundaries. Protected areas, monitoring and adaptive management are additional elements.

For State Enterprise "Melitopol Forestry" together with mission of improving regional ecological condition, there is a production issue and environmental management is part of management system of its production activities. Like any manufacturing enterprise, it must coordinate its activities with general rules of environmental safety. Wood obtained from logging is mainly sent to processing plant or processed on site. In processing plant, wood is processed into lumber and other products made of wood. At logging sites, wood is processed into technological firewood, which is exported to Zaporizhzhya Aluminum Plant. The annual export is more than $1000 \mathrm{~m}^{3}$ of wood. The plant also procures fuel chunks, which are delivered to consumers by enterprises' transport.

Essence of implementing productive method of environmental management of SE "Melitopol Forestry" lies in forestry, which acts as main independent production in enterprise's production structure. This activity's goal is forest management, protecting state ownership of forests, protecting forests from fires, protecting forests from diseases and pests. The main goal of forest management is organizing forests' usage, and thus implementing environmental management at regional level.

Organization of ecological management at State Enterprise "Melitopol Forestry" is aimed primarily at rational using natural resources of state forest fund. A great role in enterprise's activities used to belong to field afforestation, especially planting in ravines, gullies, and afforestation of unproductive lands unsuitable for agriculture, riverbanks and reservoirs. In addition, forests are of sanitary and aesthetic importance and are a rest area for this region residents. These functions are of great environmental and economic importance for regional environmental safety. 
To implement innovative methodological approaches to ensure introduction and effective functioning of environmental management system in management system of modern enterprises to achieve environmental goals of any region of the country we should take into account opinion of such authors as Lipich L. and Hlubitska T. who consider that "in order to ensure environmental management effectiveness at enterprise it is necessary:

1) To develop for each waste type progressive ways of their usage, which would not only reduce waste amount at enterprise and in forest, but also bring environmental and economic benefits.

2) To pay attention at such ways of problem solving, which would reduce production activities impact on the environment.

3) To create innovative mechanism for implementing environmental management systems at Ukrainian enterprises. In the modern period of scientific and technological progress, along with increasing environmental demands for production technologies, environmental management becomes essential decisive economic factor, which defines further effective economy development. Thus, it is necessary to consider environmental demands to management of production, new product development, marketing operations, personnel, finance, that is necessity to form environmental management at enterprises" (Lipich et al, 2013).

To ensure effectiveness of environmental management as organizational and methodological measures for their consolidation, it is reasonable to recommend the following priorities defined by authors:

- Guaranteeing comprehensive company's staff awareness of environmental goals of the region and the country.

- Improving organizational structures of enterprise management by creating environmental management department.

- Providing enterprise management system with human, technical, information resources essential for environmental management functioning.

- Enterprise adaptation to ecological legal sector not only in Ukraine, but also in other countries.

- Permanent monitoring of environnemental activités of other entreprises.

- Using world experience of ecological management implementation to achieve regional ecological goals. 
$882 \begin{aligned} & \text { Restorative and productive methods of environmental management in the implementation of } \\ & \text { environmental policy }\end{aligned}$

- Popularization and promotion of ecological values through dissemination of information on ecological legislation, experience of achieving ecological stability in countries, regions.

Recommended measures implementation should become indicators for environmental management introduction to achieve environmental goals of the region and the country.

\section{Conclusions}

Solving environmental problems is always a priority for the sustainable functioning of the regions of our country. It is substantiated that for the implementation of environmental policy it is functionally important to use productive and regenerative methods (definitions recommended in this paper) of environmental management.

The introduction of a regenerative method of environmental management to achieve the strategic goal of regional development policy requires the coordination of economic goals of enterprises that form the industrial base of the region and the goals of its environmental policy. The orientation of management at industrial enterprises to the implementation of innovative science-based measures that support environmental safety is a sign of the development of the concept of environmental management in all economic management activities.

The system of environmental management in Ukraine is defined and regulated by the Law of Ukraine "On Environmental Protection", which was adopted at the beginning of the proclamation of independent Ukraine. However, the methodological foundations that develop the environmental principles of enterprises in the region are insufficiently developed. The initiative of scientists and work on the development of environmental management methodology are promising for laying the foundations for achieving environmental policy goals.

The work was carried out within the framework of the scientific topics «Formation of an effective system management of enterprises in the region» (state registration number : 0121U109915). 


\section{Bibliographic References ${ }^{6}$}

CHYGRYN, Olena O; KRASNIAK, Viktoriia. 2015. "Theoretical and applied aspects of the development of environmental investment in Ukraine" In: Marketing and Management of Innovations. Vol. 3, No. 9, pp. 226-234.

DEPARTMENT OF ECOLOGY AND NATURAL RESOURCES. 2018. Regional state administration of Zaporizhzha. Regional report on the state of the environment in Zaporizhia region in 2017. Available online. In: https:// mepr.gov.ua. Consultation date: 10/06/2021.

GREGORY McGee. 2015. Forest ecosystem management : a new paradigm for forest biodiversity conservation. Available online. In: https:// d2ouvy59podg6k.cloudfront.net/downloads/16_toolkit_for_ universities_on_forest_ecosystem_management.pdf. Consultation date: 10/06/2021.

JAFARI, Mahtab. 2018. "Research of the role of tourism in the preservation of sustainable development of ecology: a geographical approach" In: Global Journal of Economics and Finance. Vol. 1, No. 2, pp. 24-37.

LIPICH, Lubov; HLUBITSKA, Tetiana. 2013. "Introduction of ecological management at the enterprises of the chemical complex" In: Bulletin of the National University Lviv Polytechnic. Vol. 76-9, No. 6, pp. 59-64.

MYKOLAYIV CITY COUNCIL. 2021. Ecological policy of the city of Nikolaev. Available online. In: https://mkrada.gov.ua/content/ekologichnapolitika-ta-plan-diy-na-hhi-stolittya.html. Consultation date: 13.07.2021

OLEKSENKO, Roman ; BILOHUR, Stanislav ; RYBALCHENKO, Nina ; VERKHOVOD, Iryna ; HARBAR, Halina. 2021. "The ecological component of agrotourism development under the COVID-19 pandemic" In: Cuestiones Políticas. Vol. 39, No. 69, pp. 870-881. Available online. In: https://doi.org/10.46398/cuestpol.3969.53

VARFOLOMEEV, Andrii. 2019. "Implementation of resource efficient and clean production options at Ukrainian enterprises" In: Centrum Badań i Innowacji Pro-Akademia. Vol. 30, No. 8, pp. 68-75.

ZOS-KIOR, Mykola; SHKURUPIY, Olga; GNATENKO, Iryna, FEDIRETS, Oleg; SHULZHENKO, Iryna; RUBEZHANSKAYA, Viktoriia. 2021. "Modeling of the process of formation of the investment program of ecological management of an agrarian cluster" In: European Journal of Sustainable Developmen. Vol. 10, No. 01, pp. 571583. Available online. In: https:// doi.org/10.14207/ejsd.2021.v10n1p571. Consultation date: 13/07/2021.

6 Some cited sources only have the initial of the name of the author or authors because it was impossible to locate their full name as stable the standard of this journal. 

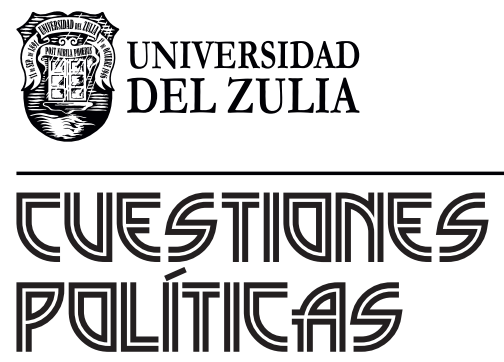

Vol. 39 N $^{\circ} 71$

Esta revista fue editada en formato digital y publicada en diciembre de 2021, por el Fondo Editorial Serbiluz, Universidad del Zulia. Maracaibo-Venezuela 